\begin{tabular}{|c|c|c|}
\hline \multirow[t]{2}{*}{ 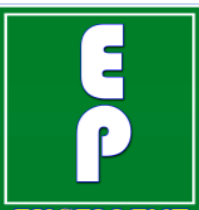 } & $\begin{array}{l}\text { International Journal of Current Research in } \\
\text { Biosciences and Plant Biology }\end{array}$ & \\
\hline & Volume $4 \bullet$ Number 8 (August-2017) • ISSN: 2349-8080 (Online) & \\
\hline $\begin{array}{l}\text { EXCELLEN } 1 \\
\text { PUBLISHERS }\end{array}$ & Journal homepage: www.ijcrbp.com & wwewilichp. com \\
\hline
\end{tabular}

\title{
Effects of Aqueous Extract of Sterculia setigera Delile (Sterculiaceae) on Exercise-Induced Bronchospasm
}

\author{
Judith F. Ahounou Aikpe ${ }^{1,2}$, B. Huguette Akakpo ${ }^{1,2}$, André Hamadou ${ }^{1}$, Serge F. Sossou ${ }^{1}$, \\ Joachim D. Gbénou ${ }^{2} *$ and Pierre H. Dansou ${ }^{1}$

\begin{abstract}
${ }^{1}$ Laboratory of Effort Physiology, National Institute of Youth, Physical and Sport Education, University of Abomey-Calavi, 01 BP 169, Porto-Novo, Republic of Benin

${ }^{2}$ Laboratory of Pharmacognosy and Essential Oils, Faculty of Sciences and Techniques University of Abomey-Calavi,
\end{abstract} \\ 01 BP 918, ISBA, Cotonou, Republic of Benin
}

*Corresponding author.

\begin{abstract}
Sterculia setigera Delile (Sterculiaceae) is a plant commonly used in African traditional medicine and pharmacopoeia to treat many pathology including cough and asthma. The present study aim to evaluate the effect of aqueous extract of Sterculia setigera leaves on exercise-induced bronchospasm in athletes. Subjects underwent a treadmill bronchial test and a spirometry test before and after treatment with this aqueous extract. The comparison of subjects ventilatory parameters is carried out and certain inflammatory proteins tested. The results showed that aqueous extract of Sterculia setigera leaves improved significantly the ventilation parameters of subjects and declined the percentage in forced expiratory volume per second $\left(\mathrm{FEV}_{1}\right)$. Subjects Blood concentration in C-reactive protein (CPR) and erythrocyte sedimentation rate were also be reduced. These results justify the traditional use of Sterculia setigera in the treatment of asthma and cough in Benin. This extract can therefore be used in the treatment of asthma or exercise-induced bronchospasm (EIB) in elite athletes.
\end{abstract}

\section{Article Info}

Accepted: 24 July 2017

Available Online: 06 August 2017

Keywords

C-reactive protein

Exercise-induced bronchospasm Sterculia setigera

\section{Introduction}

Asthma is a pathology frequently encountered in Benin (Zohoun and Flénon, 1997). It is a chronic inflammatory disease of the respiratory tract. It reveals itself in attacks of wheezing dyspnea, often nocturnal and reversible, spontaneously or under the effect of treatment (Gaillard, 2004). It is a multifactorial syndrome which expression is a function of acquired factors often linked to the environment. Asthmatics experience chest tightness, wheezing, cough and sometimes breathlessness (Godard et al., 2000).

The respiratory difficulties associated with asthma lead particularly to complications during physical activities. These are Exercise-Induced Asthma (EIA) or ExerciseInduced Bronchospasm (EIB). It is characterized by the occurrence of bronchial obstruction during physical activity, typically 5 to 15 minutes during recovery (Karila, 2002; Boulet et al., 1999). Contraction of the bronchial smooth muscles is then observed. A low 
degree of hygrometry (dry air) and a low temperature (cold air) contribute to reinforce the EIB in athletes (Karila et al., 2001). The most important manifestation of this muscular contraction is a diminution in the airway caliber which can be readily measured in a laboratory by a pulmonary function test. EIB is explained functionally by a $15 \%$ reduction in a peak expiratory flow or forced expiratory volume per second (FEV ${ }_{1}$ (Rundell et al., 2003; Backer and Ulrik., 1992).

The prevalence of EIB was $4.05 \%$ among young South Africans aged 6-20 years after a $6 \mathrm{~min}$ free run (Terblanche and Stewart, 1990). Among 21 international handball players aged 19-33 years old, the EIB prevalence was $14 \%$ (Ouatara et al., 2004). In Benin, this prevalence was $35 \%$ in basketters with a mean age of 19 years after a free-field exercise test (Mensan et al., 2008). Another study carried out in Benin in sports students revealed a prevalence of EIB equal to $40 \%$ (Agodokpessi et al., 2012).

In order to alleviate or to limit pathological risks, modern medicine was often required. In a weak economic environment characterized by the high cost of this medicine, pharmacopeia and traditional medicine become a non-negligible alternative concerning sanitary cover. Currently, more than $80 \%$ of African population has resort to the drugs essentially made of plants (WHO, 2003). In Benin flora, several species of plants were often used in the treatment of several diseases. Thus, in northern Benin, Sterculia setigera Delile (Sterculiaceae) (Akoègninou et al., 2006) is used traditionally to treat cough and asthma

Sterculia setigera was also used in the Nigerian diet (Garba, 2001) and in the pharmacopoeia as an extract in a form of drugs to treat gastroenteritis, constipation, intestinal transit, dermatosis and cough (Mogode, 2005). Toxicological, bronchodilatory and antitussive properties (Gbénou et al., 2011) and anti-inflammatory's (Ahounou, 2011) of this plant were reported in several studies.

The aim of this work is to evaluate the effect of aqueous extract of Sterculia setigera leaves on exercise-induced bronchospasm, blood sedimentation rate and C-reactive protein (CPR) of sporty athletes.

\section{Materials and methods}

\section{Plant material}

The leaves of Sterculia setigera Delile used in this study were collected from Okpara (locality in the north of Benin). The plants were identified at the institutional herbarium center (University of Abomey Calavi, Benin) with the following accession number: AA6376/HNB.

\section{Technical equipment}

$\checkmark$ A treadmill with the following characteristics: "YK-06860, frequency $50 / 60 \mathrm{~Hz}$, input voltage $220 \mathrm{~V}$, input power $2.5 \mathrm{HP}$, input current $8 \mathrm{~A}$, No. 20907292551".

$\checkmark$ A SPIROBANK II S/N 001267 MIR spirometer. The used norm is that of African ethics group incorporated in the spirometer software.

\section{Aqueous extract preparation}

Two extemporaneous decoctions were obtained from $125 \mathrm{~g}$ of Sterculia setigera leaves on the one hand and from $62.5 \mathrm{~g}$ on other hand, in 2 liters of boiled water for 30 minutes. After filtration the decoctions were stored in a thermos to keep it warm, until used.

\section{Ethical considerations}

The experiments were performed according to the Institutional Ethics opinion, $\mathrm{N}^{\circ} 002 \mathrm{MS} / \mathrm{DC} / \mathrm{SG} /$ DFRS/CNPERS/SA of March 03, 2011 (University of Abomey Calavi, Benin). The administrative authorization for research, n4079/MS/DC/SGM/ DRS/SA of July 2011 was signed by Benin Republic Health Minister.

\section{Study nature and criteria}

It is an experimental, transverse and comparative survey. The non-random and random sampling methods were used.

The subjects for the test satisfied all of inclusion and exclusion criterias imposed in the realization of this study.

\section{Constitution of experimental groups}

Three groups (G1, G2, G3) were formed on a basis of percentage of diminution in the Forced Expiratory Volume in 1 Second $\left(\mathrm{FEV}_{1}\right)$ after Exercise-Induced Bronchospasm (EIB) test on day zero $\left(\mathrm{D}_{0}\right)$ (Durand et al., 2005; Rundell and Jenkinson, 2002; Weiler and Ryan, 2000; Leuppi et al., 1997; Mannix et al., 1996). 
Positive diagnosis of EIB is based on a diminution of $\mathrm{FEV}_{1}$ at least $10 \%$. Negative diagnosis is made on a FEV1 fall of less than $10 \%$.

Calculation of the percentage of diminution in the $\mathrm{FEV}_{1}$ :

Percentage of diminution in

$\mathrm{FEV}_{1}=100 \times\left(\right.$ pre $\mathrm{FEV}_{1}-$ post $\left.\mathrm{FEV}_{1}\right) /$ pre $\mathrm{FEV}_{1}$

With pre $\mathrm{FEV}_{1}=$ Forced expiratory volume in 1 second before exercise, post $\mathrm{FEV}_{1}=$ Maximum Expiratory Volume in 1 second after exercise.

$\checkmark$ G1 is the control group with an average percentage diminution of $\mathrm{FEV}_{1}$ equal to $10.39 \%$. The subjects in this group received only half glass of warm water.

$\checkmark$ G2 is the group treated with half glass of Sterculia setigera leaves decoction at $62.5 \mathrm{~g}$ dose. The mean percentage of diminution in $\mathrm{FEV}_{1}$ in this group was $4.05 \%$.

G3 is the group treated with half glass of the decocted Sterculia setigera leaves at a dose of $125 \mathrm{~g}$. The mean percentage of diminution in $\mathrm{FEV}_{1}$ is $21.57 \%$.

Independent variable as the type of treatment with extracts and dependent ones included $\mathrm{FEV}_{1}$, forced vital capacity (FVC), Tiffeneau's report, Sedimentation Rate and C-reactive protein (CPR) were studied.

\section{Experimental protocol}

On day $\mathrm{D}_{0}$ all subjects underwent the bronchial provocation test on conveyor belt. They underwent the same test at the end of treatment on day $\mathrm{D}_{14}$, in order to compare the values. The three groups took their dose the morning between $8 \mathrm{hrs}$ and $10 \mathrm{hrs}$ during 14 days. The blood withdrawals and the analyses were carried out by the same evaluators. These blood withdrawals have been made on day $D_{0}, D_{14}, D_{15}, D_{16}$ and $D_{17}$ (five withdrawals by subject) (Fig. 1).

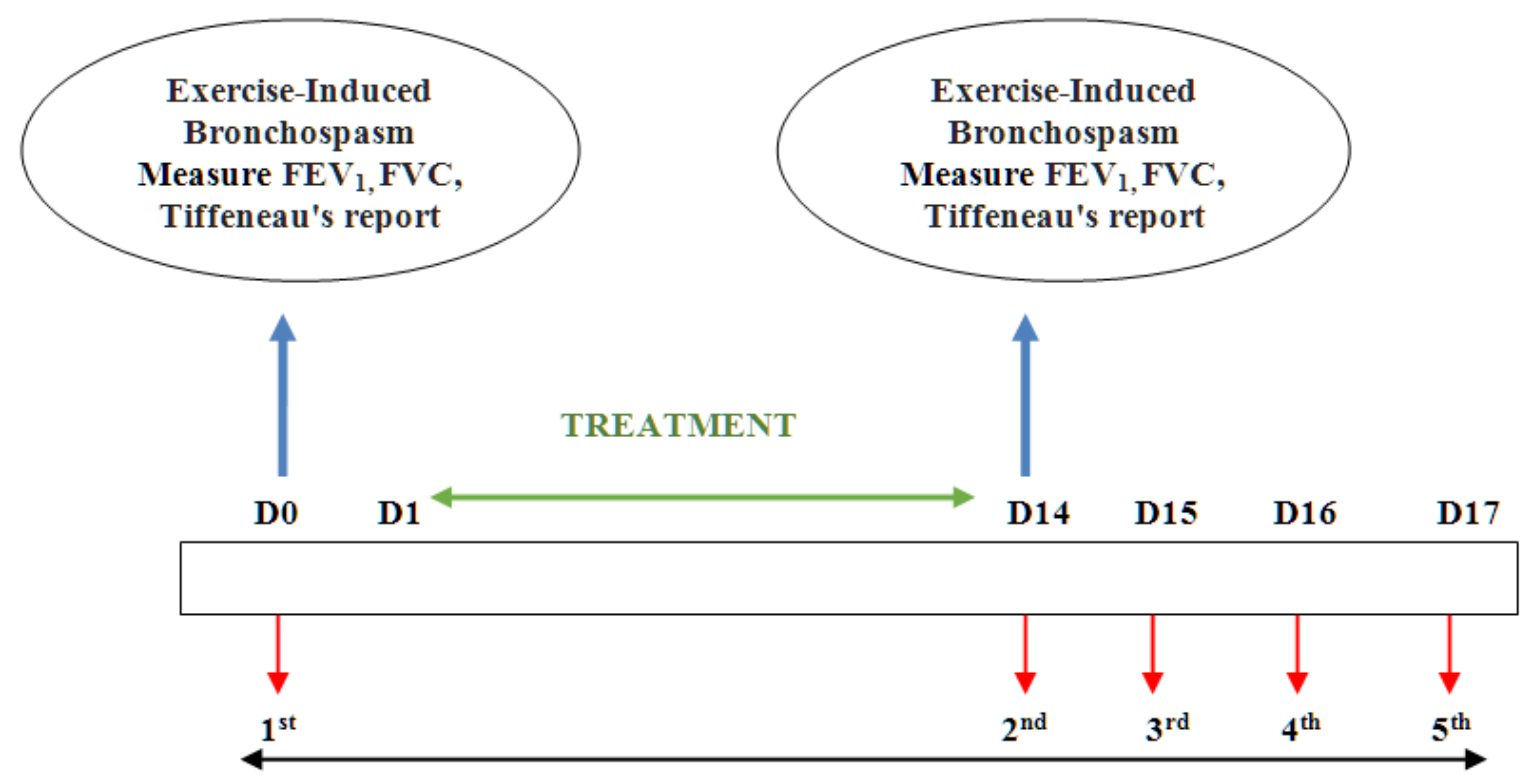

Blood concentration in C-reactive protein (CPR) and Sedimentation Rate

Fig. 1: Experimental protocol.

The mean (X), standard deviation (s) and standard error of mean (SEM) were calculated for each variable at stake. The comparison of the evolution of the various parameters was carried out by $\mathrm{T}$ test of student on independent sample on the one hand and in matched series on the other hand. The significance threshold for statistical tests was set at $p<0.05$.

\section{Results and discussion}

\section{Anthropometric characteristics of subjects}

The Table 1 indicates that there is no significant difference of the anthropometric parameters. Moreover, the subjects are relatively young. There is therefore a 
homogeneity in the study sample, which eliminates the influence of age on the results. There was no significant difference in the body mass index of the subjects in the three groups. The subjects are not obese because the different values are below $24 \mathrm{~kg} \cdot \mathrm{m}^{-2}$. They are not overweight (OMS, 2002).

Table 1. Anthropometric characteristics of studied subjects $(\mathrm{N}=45)$.

\begin{tabular}{llll}
\hline \multirow{2}{*}{ Anthropometric characteristics } & GROUPS & & \\
\cline { 2 - 4 } & G1 (N: 15) & G2 (N: 15) & G3 (N: 15) \\
\cline { 2 - 4 } & X \pm SEM & X \pm SEM & X \pm SEM \\
\hline Age $($ year) & $21.61 \pm 2.18$ & $21.67 \pm 1.80$ & $22.62 \pm 3.15$ \\
Height $(\mathrm{cm})$ & $175.00 \pm 0.06$ & $175.33 \pm 0.08$ & $173.50 \pm 0.09$ \\
MC $(\mathrm{kg})$ & $69.53 \pm 8.66$ & $69.11 \pm 11.31$ & $66 \pm 13.74$ \\
BMI $\left(\mathrm{kg} / \mathrm{m}^{2}\right)$ & $22.68 \pm 1.95$ & $22.38 \pm 2.52$ & $21.69 \pm 2.10$ \\
\hline G1: control (warm water); G2: Sterculia setigera & $(62.5 \mathrm{~g}) ;$ G3: Sterculia & setigera $(125 \mathrm{~g}) ; \mathrm{N}:$ number; X: average; SEM: \\
Standard Error of Mean; BMI: Body Mass Index.
\end{tabular}

\section{Ventilatory parameters}

\section{Prevalence of EIB}

The prevalence of the EIB $(55.55 \%)$ obtained in this study is high compared with those of many other studies (Terblanche and Stewart, 1990; Ouatara et al., 2004; Mensan et al., 2008; Agodokpessi et al., 2012). In spite of the fact that all the studies were carried out in the same conditions (hot and humid climate, $10 \%$ of diminution of $\mathrm{FEV}_{1}$ according to the diagnostic criteria of the EIB), the difference of prevalence observed with those studies may be explained by the technique used to induce the EIB. In fact, the conveyor belt, mobilizes more rapidly a high ventilator flow. It achieved $80 \%$ to $90 \%$ of theoretical heart rate or maximal $\mathrm{O}_{2}$ intake and the intensity for 04 minutes was maintained and the maximum target ventilation was obtained (Rundell et al., 2000).

\section{$\mathrm{FEV}_{1}$ and the percentage of $\mathrm{FEV}_{1}$ diminution}

The Forced Expiratory Volume in 1 second $\left(\mathrm{FEV}_{1}\right)$ was the parameter used to assert the appearance of EIB. The analysis of percentages of diminution of $\mathrm{FEV}_{1}$ shows that there is a significant difference between pre and post-treatment values within each group (Table 2). The percentage of diminution of $\mathrm{FEV}_{1}$ is very significant in group 3. The conveyor belt test has led to bronchial contraction by hyperventilation (Lumme et al., 2003), which resulted in a reduction in maximum expiratory volume per second and an increase in $\mathrm{FEV}_{1}$ diminution to $10 \%$. When the subjects are treated with the aqueous extract of Sterculia setigera at $125 \mathrm{~g}$ dose, the percentage of diminution in $\mathrm{FEV}_{1}$ falls to $95.17 \%$. This result confirms the anti-inflammatory, broncho-relaxing and anti-tussive properties of the extract (Gbénou et al., 2011; Ahounou, 2011). In addition, the chemical compounds such as flavonoids, anthocyanins, leucoanthocyans, mucilage and essential oil give to the extract anti-oedematous, anti-inflammatory, emollient, antioxidant and analgesic characteristics (Gbénou et al., 2011; Ahounou, 2011). These results corroborate those of previous works (Hijazi et al., 2000) which suggest the consumption of certain antioxidants such as flavonoids in the treatment and reduction of the occurrence of asthma. The effect of the aqueous extract of Sterculia setigera at $125 \mathrm{~g}$ dose would then correspond to that of salbutamol ( $\beta 2$ mimetic) with bronchodilatory properties (Boulet et al., 1989).

Table 2. Mean FEV1 and percentage of FEV1 diminution.

\begin{tabular}{llllllll}
\hline $\begin{array}{l}\text { Ventilatory } \\
\text { parameters }\end{array}$ & & G1 & \multicolumn{3}{c}{ G2 } & G3 & \\
\cline { 2 - 7 } & Before & After & Before & After & Before & After \\
\hline $\mathrm{FEV}_{1}(\mathrm{~L} / \mathrm{min})$ & Pre & $3.23 \pm 0.27$ & $3.49 \pm 0.25$ & $3.27 \pm 0.29$ & $3.33 \pm 0.62$ & $3.09 \pm 0.60$ & $3.13 \pm 0.65$ \\
& Post & $3.59 \pm 0.27$ & $3.2 \pm 0.32$ & $2.97 \pm 0.38$ & $3.28 * \pm \mathbf{0 . 4 6}$ & $2.42 \pm 0.50$ & $\mathbf{3 . 0 2} * \pm \mathbf{0 . 4 6}$ \\
$\Delta \mathrm{FEV}_{1}$ & & $-10.39 \pm 1.46$ & $\mathbf{- 8 . 9 3} * \pm \mathbf{1 . 2 9}$ & $4.05 \pm 1.82$ & $\mathbf{- 1 1 . 8 6 * \pm \mathbf { 4 . 0 8 }}$ & $21.57 \pm 4.50$ & $\mathbf{1 . 0 4} * \pm \mathbf{0 . 9 3}$ \\
\hline
\end{tabular}

G1: control (warm water); G2: Sterculia setigera (62.5 g); G3: Sterculia setigera (125 g); SEM: Standard Error of Mean; Before: before treatment; After: after treatment; $F_{1} V_{1}$ pre: Forced Expiratory Volume in a second before exercise; FEV ${ }_{1}$ Post: Max Expiratory Volume per second after exercise; $\Delta \mathrm{FEV}_{1}$ : Percentage of diminution in $\mathrm{FEV}_{1}$ before and after treatment; *: Significant values. 


\section{Tiffeneau's Report (FEV/FVC)}

The mean values of Tiffeneau ratio obtained in G2 and G3 are lower than that of G1 (Table 3). These values in G1 indicate the onset of respiratory difficulties (Tiffeneau and Pinelli, 1948). This ratio increased after 14 days of treatment in G2 and significantly in G3. The aqueous extract of Sterculia setigera reduced the respiratory difficulties.

\section{Sedimentation rate and CRP blood concentration}

The sedimentation rate declined after the treatment of all subjects regardless the group of affiliation. This diminution is highly significant in G3 (Table 4). The aqueous extract of Sterculia setigera reduced inflammation in subjects.

At hepatic level (Gabay and Kushner, 1999), cytokines modify the results of proteins in an acute phase: Creactive protein, amyloid A serum (AAS), haptoglobin, orosomucoid, fibrinogen. Among these proteins, Creactive protein (CRP) is currently recognized as the marker of choice for inflammatory response. Increasingly knowledge of its functions considers CRP as a key player in innate immunity and a protagonist of accelerated atherogenesis (Dupuy et al., 2003).

It is a marker which concentration increases with the degree of inflammation. The inflammation is then the common point of bronchial hyperresponsiveness (BHR) and also refers to the reduction of airway size, hypertrophy and hyperplasia of smooth muscle fibers, and lesions of epithelial barrier (Molliex, 2004). The plasma concentration of the C-reactive protein (CRP) rises immediately after the introduction of an antigen into the body and it disappears later when an antibody is formed (Volanakis, 2001).

The C-reactive protein (CRP) was declined in the blood after treatment of all subjects (Table 5). This diminution is highly significant in group 3 . This is due to the active constituents (tannins, alkaloids, flavonoids, mucilages, anthocyanins) with anti-inflammatory properties noted by the previous works on the aqueous extract of Sterculia setigera (Gbénou et al., 2011).

Table 3. Tiffeneau's report $\left(\mathrm{FEV}_{1} / \mathrm{FVC}\right)$ according to the type of treatment.

\begin{tabular}{|c|c|c|c|c|c|c|}
\hline \multirow{2}{*}{$\begin{array}{l}\text { Ventilatory } \\
\text { parameters }\end{array}$} & \multicolumn{2}{|l|}{ G1 } & \multicolumn{2}{|l|}{ G2 } & \multicolumn{2}{|l|}{ G3 } \\
\hline & Before exercise & After exercise & Before exercise & After exercise & Before exercise & After exercise \\
\hline FEV1/FVC & $0.86 \pm 0.02$ & $0.88 \pm 0.02$ & $0.70 \pm 0.01$ & $0.83 * \pm 0.03$ & $0.68 \pm 0.00$ & $0.89 * \pm 0.03$ \\
\hline
\end{tabular}

Table 4. Sedimentation rate at the first and second hour.

\begin{tabular}{|c|c|c|c|c|c|c|c|}
\hline \multirow{2}{*}{\multicolumn{2}{|c|}{$\begin{array}{l}\text { Blood } \\
\text { parameters }\end{array}$}} & \multicolumn{2}{|l|}{ G1 } & \multicolumn{2}{|l|}{ G2 } & \multicolumn{2}{|l|}{ G3 } \\
\hline & & $1^{\text {st }}$ hour & $2^{\text {nd }}$ hour & $1^{\text {st }}$ hour & $2^{\text {nd }}$ hour & $1^{\text {st }}$ hour & $2^{\text {nd }}$ hour \\
\hline \multirow{2}{*}{ SR } & Before & $5.51 \pm 0.04$ & $10.69 \pm 0.23$ & $5.61 \pm 0.05$ & $17.33 \pm 2.05$ & $10.62 \pm 1.33$ & $16.37 \pm 1.93$ \\
\hline & After & $4.23 \pm 0.03$ & $10.38 \pm 0.19$ & $4.22 \pm 0.03$ & $8.44 \pm 0.72 *$ & $5.37 \pm 0.07$ & $6.77 \pm .12 *$ \\
\hline
\end{tabular}

G1: control (warm water); G2: Sterculia setigera (62.5 g); G3: Sterculia setigera (125 g); SEM: Standard Error of Mean; Before: before treatment; After: after treatment; SR: Sedimentation rate; *: Significant values.

Table 5. C-reactive protein (CRP).

\begin{tabular}{llll}
\hline CRP $(\mathbf{m g} / \mathbf{L})$ & G1 & G2 & G3 \\
\hline Before & $1.23 \pm 0.00$ & $2.33 \pm 0.01$ & $7.50 \pm 1.30$ \\
After & $0.30 \pm 0.00$ & $\mathbf{0 . 4 4} \pm \mathbf{0 . 0 0 *}$ & $\mathbf{1 . 1 2 \pm 0 . 0 0 *}$ \\
\hline
\end{tabular}

G1: control (warm water); G2: Sterculia setigera (62.5 g); G3: Sterculia setigera (125 g); SEM: Standard Error of Mean; Before: before treatment; After: after treatment; CRP: C-reactive protein; *: Significant values.

These results confirm the effectiveness of the aqueous extract of Sterculia setigera in traditional treatment of exercise-induced asthma.

\section{Conclusion}

The results of the study showed that a treatment with 
aqueous extract of Sterculia setigera leaves had a positive effect on EIB subjects. Aqueous extract reduced the percentage of diminution in $\mathrm{FEV}_{1}$, blood C-reactive protein and erythrocyte sedimentation rate. An improvement was observed in the treated groups $(\mathrm{G} 2$ and G3) compared to the control group (G1). This improvement is more noticeable in (G3).

In view of these results, aqueous extract of Sterculia setigera leaves is a bronchodilator in the same way as salbutamol since it has made it possible to aerate the airways and facilitate the breathing in sportsmen. It can therefore be used in the treatment of exercise-induced asthma or EIB in elite athletes.

\section{Conflict of interest statement}

Authors declare that they have no conflict of interest.

\section{References}

Agodokpessi, G., Adé, G., Ahounou, F.J., Gbénou, D. J., Dansou, H. P., Gninafon, M., 2012. L'asthme induit par l'exercice de l'athlète en climat chaud et humide. Mali Med. J. 27, 33-36.

Ahounou, F. J., 2011. Evaluation de l'activité des extraits aqueux de Sterculia setigera et du mélange Aframomum melegueta (Roscoe) K. Schum (Zingiberaceae) Citrus aurantifolia (Christm et Panzer) Swingle (Rutaceae) sur l'asthme induit par l'effort . Thèsede Doctorat en Pharmacologie des Substances Naturelles et Physiologie de l'Effort au Benin. pp.85-89.

Akoègninou, A., van der Burg Jvan der Maesen, L.J.G., Adjakidjè, V., Essou, J.P., Sinsin, B., Yédomonhan, H., 2006. Flore Analytique du Bénin. Backhuys Publisher: Cotonou et Wagenigen. pp.103-104.

Backer, V., Ulrik, C.S., 1992. Bronchial responsiveness to exercise in a random sample of 494 children and adolescents from Copenhagen. Exp. Allergy. 22(8), 741-752.

Boulet, L.P., Turcotte, H., Tennina, S., 1989. Comparative efficacy of salbutamol, ipratropium, and cromoglycate in the prevention of bronchospasm induced by exercise and hyperosmolar challenges. J. Allergy. Clin. Immunol. 83(5), 882-887.

Boulet, L.P., Becker, A., Berube, D., Beveridge, R., Ernst, P., 1999. Summary of the recommendations of the Canadian Consensus Conference on Asthma. Canadian Asthma Consensus Group. CMAJ.161, 1-
14.

Dupuy, A. M., Terrier, N., Sénécal, L., Morena, M., Leray, H., Canaud, B. J., Cristol, P., 2003. La CRP est-elle plus qu'un marqueur de l'inflammation? Nephrol. 24(7), 337-341.

Durand, F., Kippelen, P., Ceugniet, F., Gomez, V.R., Desnot, P., Poulain, M., Prefaut, C., 2005. Undiagnosed exercise-induced bronchoconstriction in ski-mountaineers. Int. J. Sports Med. 26 (3), 233237.

Gabay, C., Kushner, I., 1999. Acute-phase proteins and other systemic responses to inflammation in $\mathrm{N}$. Engl. J. Med. 340, 448-454.

Gaillard, F., 2004. Asthme induit par l'exercice 2010. $\mathrm{http} / / \mathrm{www} . p l g S p o r t s . b e / u p l o a d / i n f o n e w s / a s t h m a$ induit par l'exercice; consulté le 11-05.

Garba, H., 2001. Les Produits Forestiers Non ligneux au Niger: Connaissances actuelles et tendances. Programme de partenariat CE - FAO 1998-2001. Ligne budgétaire forêt tropicale B7-6201/97- 15 VIII/For. Projet GCP/Int/679 EC.

Gbénou, D. J., Ahounou, M., Ladouni, F. J., Agbodjogbé, P., Tossou, D. D.W., Dansou, R., Moudachirou, H. P., 2011. Propriétés antiinflammatoires des extraits aqueux de Sterculia setigera Delile et du mélange Aframomum melegueta K. Schum-Citrus aurantifolia Christm et Panzer Int. J. Biol. Chem. Sci. 5(2), 634-641.

Godard, P., Chanez, P., Bousquet, J., Demoly, P., Michel, F.B., Pujol, J.L., 2000. Asthmologie. Paris, $2^{\text {ed }}$ Edn. Masson. 300p.

Hijazi, N., Abalkhail, B., Seaton, A., 2000. Diet and childhood asthma in a society in transition: A study in urban and rural Saudi Arabia. Thorax. 55(9), 775779.

Karila, C., 2002. Asthme induit par l'exercice. Dutau Actualitesen Pneumologieet Allergologie, Paris, Elsevier Editions. pp.38-43.

Karila, C., de Blic, J., Waernessyckle, S., Benoist, M.R., Scheinmann, P., 2001. Cardiopulmonary exercise testing in children: An individualized protocol for workload increase. Chest. 120, 81-87.

Leuppi, J.D., Kuhn, M., Comminot, C., Reinhart, W.H., 1997. High prevalence of bronchial hyper responsiveness and asthma in ice hockey players. Eur. Respir. J. 12(1), 13-16.

Lumme, A., Haahtela, T., Ounap, J., Rytila, P., Obase, Y., Helenius, M., Remes, V., Helenius, I., 2003. Airway inflammation, bronchial hyper responsiveness and asthma in elite ice hockey players. Eur. Respir. J. 22(1), 113-117. 
Mannix, E.T., Farber, M.O., Palange, P., Galasetti, P. F., 1996. Manfredi exercise-induced asthma in figure skaters. Chest. 109, 312-315.

Mensan, F., Lounana, J., Medelli, J., 2008. Bronchospasme induit par l'exercice en climat chaud et humide au Bénin. Med. Trop. 68(5), 550-558.

Mogode, D.J., 2005. Etude phytochimique et pharmacologique de Cassia migricans Vahl utilisé dans le traitement des dermatoses au Tchad. Thesede Doctorat de Pharmacie, Mali. pp.200-223.

Molliex, S., 2004. Hyper-réactivité Bronchique Conferences D'actualisation. pp.81-90.

OMS, 2002. Médecine Traditionnelle: Rapport du Secrétariat du Conseil Exécutif; Cent onzième session : Point 5.7 de l'ordre dujour provisoire. EB 111/9 du 12 décembre 2002.

Ouatara, S., Sery, J., Kéita, M., Touré, M., Sirasy, E.A., Tuo, N., 2004. Bronchospasme induit par l'exercice chez les handballeuses vivant en climat tropical humide. RMR. 21(1), 30-38.

Rundell, K.W., Jenkinson, D. M., 2002. Exerciseinduced bronchospasm in the elite athletes. Sports Med. 32(9), 583-600.

Rundell, K.W., Spiering, B.A., Judelson, D.A., Wilson, M.H., 2003. Bronchoconstriction during crosscountry skiing: is there really or refractory period. Med. Sci. Sports. Exerc. 35(1), 18-26.
Rundell, K.W., Wilber, R.L., Szmedra, L., Jenkinson, D.M., Mayers, L. B., Im, J., 2000. Exercise induced asthma screening of elite athletes: field versus laboratory exercise challenge. Med. Sci. Sports. Exerc. 32(2), 309-316.

Terblanche, E., Stewart, R.I., 1990. The prevalence of exercise-induced bronchoconstriction in Cape Town school children. S. Afr. Med. J. 78(12), 744-747.

Tiffeneau, R., Pinelli, A., 1948. Régulation bronchique de la ventilation pulmonaire. J. Fr. Méd. Chir. Thorac. 2, 221-244.

Volanakis, J.E., 2001. Human C-reactive protein: Expression, structure, and function. Mol. Immunol. 38, 189-197.

Weiler, J.M., Ryan, E.J., 2000. Asthma in United States Olympic athletes who participated in the olympic winter games. J. Allergy. Clin. Immunol. 106, 267271.

WHO, 2003. World Health Organisation. Observatory of Health in Africa. Traditional Medicine, Our Culture, Our Future. Regional Magazine Office of the WHO, 4(1), 4p.

Zohoun, T., Flénon, J., 1997. La médecine traditionnelle et la pharmacopée africaines peuvent-elles constituer une alternative de soins face aux coûts prohibitifs actuels de la médecine moderne? Pharm. Med. Trad. Afr. 9, 3-16.

\section{How to cite this article:}

Ahounou Aïkpe, J. F., Huguette Akakpo, B., Hamadou, A., Sossou, S. F., Gbénou, J. D., Dansou, P. H., 2017. Effects of aqueous extract of Sterculia setigera Delile (Sterculiaceae) on exercise-induced bronchospasm. Int. J. Curr. Res. Biosci. Plant Biol. 4(8), 8-14. doi: https://doi.org/10.20546/ijcrbp.2017.408.002 